\title{
PENGEMBANGAN LKPD BERBASIS PBL (PROBLEM BASED LEARNING) UNTUK MENINGKATKAN KETERAMPILAN BERPIKIR KRITIS PESERTA DIDIK PADA MATERI KESETIMBANGAN KIMIA
}

\author{
Sry Astuti, Muhammad Danial ${ }^{1}$, Muhammad Anwar ${ }^{2}$ \\ ${ }_{1,2}$ Dosen Program Pascasarjana Universitas Negeri Makassar \\ E-mail: sry.astuti@ymail.com
}

\begin{abstract}
ABSTRAK
Penelitian ini merupakan penelitian pengembangan yang bertujuan mengembangkan LKPD berbasis PBL untuk meningkatkan keterampilan berpikir kritis peserta didik pada materi kesetimbangan kimia yang valid, praktis dan efektif digunakan. Model pengembangan yang digunakan dalam penelitian ini mengacu pada model pengembangan Hannafin \& Peck, yang terdiri dari tahapan penilaian kebutuhan (need assessment), desain (design), dan pengembangan (develop) dan implementasi (implementation). LKPD berbasis PBL yang telah dikembangkan, divalidasi oleh dua orang ahli. Uji coba LKPD dilakukan di SMA Negeri 21 Makassar pada kelas XI-IPA4 dengan jumlah peserta didik sebanyak 35 orang. Uji coba ini dilakukan untuk menguji keefektifan dengan memberikan angket respon peserta didik, pengamatan aktivitas peserta didik dan test keterampilan berpikir kritis, kemudian menguji kepraktisan dilakukan pengamatan keterlaksanaan LKPD, angket respon guru dan lembar pengamatan aktivitas guru. Hasil penelitian menunjukkan bahwa LKPD berbasis PBL yang dikembangkan telah dilakukan validasi, yang dinyatakan sangat valid. LKPD berbasis PBL dikatakan praktis dan efektif, karena pada uji kepraktisan yang berhubungan dengan: (1) keterlaksanaan LKPD, menunjukkan seluruh aspek dalam pembelajaran berada pada kategori terlaksana seluruhnya, (2) guru memberikan respon yang positif terhadap LKPD yang digunakan, dan (3) kesesuaian ativitas guru dengan model pembelajaran berbasis masalah berada pada batas interval toleransi. LKPD ini juga memenuhi kriteria keefektifan, dengan hasil: (1) Aktivitas peserta didik berada pada batas interval toleransi; (2) Keterampilan berpikir kritis mengalami peningkatan dengan nilai rata-rata $\mathrm{N}$-Gain sebesar 0,824 yang termasuk dalam kategori tinggi, dan (3) Peserta didik memberikan respon yang positif terhadap LKPD berbasis PBL yang digunakan.
\end{abstract}

Kata kunci: Pengembangan, LKPD Berbasis PBL, Keterampikan Berpikir Kritis, Kesetimbangan Kimia

\begin{abstract}
This research is a development research aimed at developing LKPD based on PBL to improve students' critical thinking skills on valid, practical and effective chemical equilibrium materials used. The development model used in this study refers to the Hannafin \& Peck development model, which consists of the needs assessment, design, and development and implementation. LKPD-based PBL that has been developed, validated by two experts. LKPD trials conducted in SMA Negeri 21 Makassar in class XI-IPA4 with the number of students as many as 35 people. These trials were conducted to test the effectiveness by providing a questionnaire for the learners 'responses, observing learners' activities and test critical thinking skills, then testing the practicality of observing the implementation of LKPD, teacher response questionnaires and teacher activity observation sheets. The result of the research shows that LKPD based on PBL that has been developed has validation, which stated very valid. LKPD based on PBL is said to be practical and effective, because in the test of practicality related to: (1) LKPD implementation, showing all aspects of learning are in
\end{abstract}


complete category, 2) teachers respond positively to LKPD used, and (3) the suitability of the teacher's activity with the problem-based learning model lies at the limit of the tolerance interval. This LKPD also meets the criteria of effectiveness, with results: (1) Student activity is at the tolerance interval limit; (2) critical thinking skills have increased with the average value of N-Gain of 0.824 included in the high category, and (3) Learners respond positively to LKPD based on PBL used.

Keywords: Development, LKPD Based PBL, Critical Thinking Skills, Chemical Equilibrium

\section{PENDAHULUAN}

Proses pembelajaran yang diselenggarakan di Sekolah berlandaskan pada kurikulum yang berlaku. Dewasa ini telah dilaksanakan kurikulum baru yaitu kurikulum 2013, dimana sebelumnya adalah kurikulum tingkat satuan pendidikan (KTSP). Kurikulum 2013 menginginkan proses pembelajaran yang lebih berpusat pada peserta didik untuk mengembangkan kreativitas, menciptakan kondisi yang menyenangkan, menantang dan kontekstual (Irmayanti, 2015). Hal inilah yang menuntut proses pembelajaran untuk selalu mengubah konsep berpikir peserta didik, oleh karena itu dalam kegiatan proses pembelajaran tidak hanya sekadar mentransfer pengetahuan guru ke peserta didik, namun harus melibatkan proses kognitif peserta didik secara aktif sehingga peserta didik dapat memahami dengan baik konsep-konsep yang disampaikan oleh guru melalui proses berpikir secara mendalam dan tingkat tinggi. Proses berpikir secara mendalam tersebut salah satunya dengan berpikir kritis agar dapat mengkrontruksi pengetahuannya sehingga lebih baik lagi.

Berdasarkan Hasil wawancara dengan salah seorang Guru di SMAN 21 Makassar diperoleh bahwa guru belum pernah menggunakan model pembelajaran berbasis masalah (PBL) dalam mengajarkan materi kimia. Hal ini terjadi baik pada pembelajaran yang di dalam kelas maupun yang menggunakan percobaan (eksperimen). Guru tersebut masih menggunakan proses pembelajaran yang disampaikan secara konvensional (metode ceramah). Peserta didik kurang terlibat secara aktif dalam proses pembelajaran ini. Dominasi guru dalam proses pembelajaran ini menyebabkan peserta didik lebih banyak memperoleh pengetahuan yang disampaikan oleh guru, daripada mencari dan menemukan sendiri pengetahuan, keterampilan, serta sikap yang mereka butuhkan. Hal ini yang dapat membuat sebagian peserta didik susah untuk mengembangkan dan mengkonstruk kemampuan berpikir kritisnya. Dengan menggunakan metode ini materi yang didapatkan dan diberikan secara langsung tanpa adanya proses umpan balik. Hal ini menyebabkan sebagian peserta didik kurang memahami materi yang disampaikan pada saat pembelajaran. Menyebabkan peserta didik pada saat diberikan tugas atau saat ulangan akan cenderung menyontek.

Hasil wawancara lain juga diperoleh bahwa peserta didik pernah diukur keterampilan berpikir kritis, namun hasil yang diperoleh masih rendah. Sehingga dari hasil tersebut belum dapat mengasah dan meningkatkan keterampilan berpikir kritisnya. Hal ini terbukti ketika diberikan soal-soal yang berhubungan dengan berpikir kritis, peserta didik belum mampu menjawab soal-soalnya sesuai dengan indikator berpikir kritis yaitu memberikan penjelasan sederhana, membangun keterampilan dasar, mengatur strategi dan taktik, memberikan penjelasan lebih lanjut dan menyimpulkan. Dari soal tersebut peserta didik belum mampu menjawab soal dengan baik dan benar. Sehingga perlu dikembangkan lagi kemampuan berpikir kritis peserta didik tersebut. Kemampuan berpikir kritis 
diperlukan dalam proses pembelajaran, karena dengan kemampuan berpikir tersebut peserta didik akan mampu mengaitkan materi pelajaran kimia yang diperoleh dengan kehidupan sehari-hari.

Wahyuni (2015) berpikir kritis merupakan suatu bentuk pemikiran yang berusaha memahami masalah secara mendalam, memiliki pemikiran terbuka terhadap keputusan dan pendapat orang lain, berusaha mengerti dan mengevaluasi secara benar informasi yang diterima sebelum mengambil keputusan serta mampu menghubungkan antara sebab dan akibat dalam menemukan pemecahan masalah yang dihadapi baik dalam kegaiatan proses pembelajaran maupun dalam lingkungan kehidupan sehari-hari.

Serta berdasarkan hasil wawancara lain dengan salah seoarang Guru di SMAN 21 Makassar, dalam proses pembelajaran kimia belum menggunakan LKPD yang dikembangkan dengan model pembelajaran berbasis masalah sebagai sumber belajarnya, namun hanya menggunakan buku pegangan yang diberikan disekolah tanpa ada tambahan sumber belajar lainnya. Hal inilah menyebabkan kurang memotivasi peserta didik untuk dapat bebas melakukan kegiatan pembelajaran serta kurang mengasah kemampuan berpikir kritis peserta didik.

LKPD yang banyak beredar di sekolah-sekolah saat ini masih bersifat umum dan sebagian besar hanya berisi ringkasan materi. Materi yang disajikan biasanya bersifat instan tanpa disertai penjelasan detail dan tidak ada petunjuk penggunaan LKPD bagi guru dan siswa. Hal ini akan menyebabkan peserta didik kurang tertarik pada LKPD yang ada dan kurang mengasah kemampuan berpikir kritis peserta didik. Serta pengemasan materi yang cenderung kurang bermakna bagi siswa menyebabkan peserta didik hanya menghafal materi tanpa memahami konsep yang ada sehingga mudah dilupakan dan ketika diberikan soal yang sedikit bervariasi, peserta didik akan mengalami kebingungan.

Masalah-masalah

dalam pembelajaran diatas dapat diatasi dengan menggunakan suatu model pembelajaran yang dapat melibatkan peserta didik dalam proses pembelajaran. Salah satu model pembelajarannya yaitu model Problem Based Learning (PBL). Pembelajaran berbasis masalah (PBL) lebih mendorong peserta didik untuk mengembangkan rasa ingin tahunya agar dapat mengeksplorasi pengetahuan yang dimilikinya. Pembelajaran ini juga membuat peserta didik dapat belajar mandiri dari permasalah yang diberikan. Sehingga dari proses pencarian dan pemecahan masalah itulah dapat mengkonstruk kemampaun berpikir peserta didik.

Hubungan antara pembelajaran PBL dan keterampilan berpikir kritis yakni dengan menggunakan pembelajaran PBL guru dapat melatihkan keterampilan berpikir kritis peserta didik, karena ketika siswa melakukan proses pencarian pemecahan masalah yang diberikan, peserta didik akan menggunakan sistem berpikir mereka yakni menggunakan pengetahuan awal yang berhubungan dengan indikator berpikir kritis yaitu memberikan penjelasan sederhana dan membangun keterampilan dasar. Serta pada saat proses pengumpulan data dari permasalahan yang ada, maka peserta akan menggunakan keterampiran berpikir kritis yang berhubungan dengan mengatur taktik dan strategi. Kemudian dari pemecahan masalah yang diperoleh dihubungkan dengan teori yang mengarahkan kepada keterampilan berpikir kritis yaitu memberikan penjelasan lebih lanjut karena teori yang diperoleh harus dipahami dan dijelaskan sampai akan terbentuk sebuah teori dan argumen yang relevan. Terakhir dari teori yang diperoleh dilakukan evaluasi yang berhubungan dengan keterampilan berpikir krtis yaitu menyimpulkan hasil dari proses penemuan sampai mereka dapat menyelesaikan suatu permasalahan. 
Dalam menjelaskan model pembelajaran berbasis masalah (PBL) agar dapat mengembangkan kemampuan berpikir peserta didik tersebut digunakan LKPD. LKPD yang digunakan tersebut berlandaskan model pembelajaran berbasis masalah (PBL). LKPD berbasis PBL digunakan agar dapat mengaktifkan dan mengkontruksi kemampuan berpikir kritis peserta didik melalui pemberian masalah yang ada dalam kegiatan LKPD tersebut. Serta dengan menggunakan LKPD berbasis Problem Based Learning (PBL) dapat mengasah dan meningkatkan kemampuan berpikir kritis peserta didik karena dengan LKPD berbasis PBL peserta didik mampu menggunakan kemampuan berfikir kritis, terlibat penuh dalam mengupayakan proses pembelajaran yang efektif, pembelajaran dalam pemberian masalah yang berhubungan dengan kehidupan nyata dan peserta didik terlibat aktif dalam proses pembelajaran. Hal ini menyebabkan peserta didik lebih mudah untuk mempelajarinya serta diharapkan dapat menguasai konsep-konsep penting yang disajikan dalam pembelajaran kimia khususnya materi kesetimbangan kimia. Dari kegiatan tersebut dapat mengasah kemampuan berpikir kritis perseta didik tersebut.

LKPD merupakan materi ajar yang dikemas sedemikian rupa agar peserta didik dapat mempelajari materi tersebut secara mandiri, sehingga peserta didik jadi lebih aktif untuk memecahkan masalah yang ada melalui kegiatan diskusi kelompok, praktikum, dan kegiatan menjawab permasalahan yang berhubungan dengan kehidupan seharihari. Hal ini menjadikan peserta didik akan lebih tertantang dalam proses kegiatan pembelajaran tersebut daripada pembelajaran yang hanya sekedar satu arah saja. Kegiatan memecahkan masalah yang ada dalam LKPD tersebut yang nantinya dapat berimbas pada peningkatan cara berpikirnya termasuk berpikir kritis.

dalam kegiatan pembelajaran dapat

mendorong siswa untuk mengolah bahan yang pelajari, baik secara individu maupun bersama dengan temannya dalam bentuk diskusi kelompok. LKPD juga dapat memberikan kesempatan penuh kepada peserta didik untuk mengungkapkan kemampuannya dalam keterampilan pengembangan proses berpikir melalui mencari, menebak bahkan menalar.

Dalam LKPD berbasis PBL, banyak dari materi-materi pada bidang studi kimia yang cocok disampaikan, misalnya asam-basa, larutan elektolit dan nonelektolit, reaksi redoks, laju reaksi, kesetimbangan kimia dan lain-lain. Adapun materi yang dipilih dan dimasukan dalam pembuatan LKPD berbasis PBL ini yaitu materi kesetimbanngan kimia, karena kesetimbangan kimia merupakan salah satu materi yang memiliki bahasan yang cukup luas dan memerlukan kemampuan analisis, sehingga mempengaruhi minat peserta didik dalam pembelajaran.

Berdasarkan hasil wawancara dengan salah satu Guru di SMAN 21 Makassar materi kesetimbangan kimia kurang menarik dipelajari. Hal ini karena materinya bersifat abstrak, namun juga karena selama ini guru hanya menerangkan saja tanpa adanya bahan ajar yang menarik digunakan dalam proses pembelajaran. Bahan ajar yang digunakan berupa buku pegangan yang berikan di sekolah tanpa ada bahan ajar lainnya. Hal ini menyebabkan peserta didik sulit untuk memahami materi tersebut yang berakibat pada ketuntasan belajar peserta didk tidak tercapai.

Sesuai dengan pernyataan Kadhafi, dkk (2013) yang pernyataan bahwa salah satu materi kimia yang sebagian besar konsepnya abstrak yaitu kesetimbangan kimia, yang sehingga sulit untuk diamati secara kasat mata (tingkat mikroskopis). Karakteristik materi kesetimbangan kimia yang bersifat abstrak ini kemungkinan dapat menyebabkan peserta didik mengalami kesulitan dalam memahami konsep-konsep yang terdapat didalamnya. 
Dari pernyataan-pernyataan diatas akan dilakukan suatu pengembangan bahan ajar yaitu LKPD, mengingat LKPD menjadi suatu yang harus dimiliki guru dan peserta didik dalam proses pembelajaran, dimana LKPD yang dikembangkan merupakan LKPD yang berdasarkan model pembelajaran berbasis masalah (PBL), hal ini dilakukan karena proses pembelajaran dengan PBL akan dapat mengaktifkan peserta didik dalam menjawab atau memecahkan setiap masalah yang ada dalam LKPD yang disajikan dan permasalahannya pun berhubungan dengan konteks kehidupan sehari-hari salah satunya materi kesetimbangan kimia, sehingga peserta didik akan menjadi lebih senang dalam kegiatan pembelajaran tersebut, dan berimbas pada peningkatan kemampuan berpikir kritisnya selama dalam proses pemecahan masalah tersebut.

Pengembangan LKPD berbasis PBL dilakukan, mengingat bahwa di SMAN 21 Makassar belum pernah menggunakan LKPD berbasis PBL dalam proses pembelajarannyan. Selain pengembangan LKPD berbasis PBL, juga dilakukan pengembangan perangkat lainnya yaitu berupa RPP yang berbasis PBL, buku siswa dan soal-soal yang sesuai dengan indikator kemampuan berpikir kritis.

Sehubungan dengan latar belakang di atas mendorong peneliti untuk mengambil judul penelitian "Pengembangan LKPD Berbasis PBL untuk Meningkatkan Keterampilan Berpikir Kritis Peserta Didik pada Materi Kesetimbangan Kimia”. LKPD ini nanti diharapkan bisa digunakan sebagai media pembelajaran bagi siswa dan mempermudah dalam menyampaikan materi.

Adapun dalam mengembangkan LKPD berbasis PBL ini menggunakan model yang dikembangkan oleh Hannafin \& Peck yang terbagi dalam tiga tahap yaitu penilaian kebutuhan (need assessment), desain (design) dan pengembangan dan implementasi. Pemilihan model ini karena model pengembangan Hannafin \& Peck merupakan model pengembangan yang berbasis produk. Salain itu ketiga tahap dalam model pengembangan tersebut dilakukan secara sistematik (terstruktur) yang dimulai dari menganalisis kebutuhan peserta didik agar dapat dilakukan penanganan yang tepat terhadap kesenjangan atau masalah yang dihadapi peserta didik maupun pendidik dalam pembelajaran. Kemudian itu dilakukan desain dan pengembangan terhadap kesenjangan atau masalah yang dihadapi peserta didik maupun pendidik dalam pembelajaran. Serta dalam mengaplikasikan model tersebut lebih mudah karena langkah/tahap dalam model ini lebih sedikit daripada model-model pengembangan yang ada.

\section{METODE PENELITIAN}

Jenis penelitian ini digolongkan dalam penelitian dan pengembangan yang akan menghasilkan produk berupa LKPD berbasis PBL untuk meningkatkan keterampilan berpikir kritis peserta didik pada materi Kesetimbangan Kimia. Adapun desain penelitian ini mengikuti model Pengembangan Hannafin dan Peck. Model ini terdiri dari tiga tahap pengembangan yaitu tahap analisis kebutuhan, desain dan pengembangan dan implementasi.

Pelaksanaan

penelitian pengembangan ini dilakukan pada Tanggal 08 sampai 19 Januari 2018. Penelitian ini melibatkan guru model, yaitu peneliti sendiri, dan dua pengamat yaitu St. Batari, S.Pd, M.Si dan M. Nasir, S.Pd, M.Si, yang merupakan guru kimia di SMAN 21 Makassar. LKPD Berbasis PBL yang telah dikembangkan, divalidasi oleh para ahli, dan diujicobakan di SMA (Sekolah Menengah Atas) Negeri 21 Makassar kecamatan Tamalanrea kota Makassar semester ganjil tahun pelajaran 2017/2018. Adapun subjek uji coba penelitian ini adalah peserta didik kelas XI yang terdaftar pada tahun pelajaran 2017/2018. 
Instrumen penelitian yang digunakan adalah lembar validasi LPKD, RPP dan Tes KBK, lembar observasi keterlaksanaan LKPD, lembar observasi aktivitas guru, lembar observasi aktivitas peserta didik, angket respon peserta didik, angket respon guru, tes keterampilan berpikir kritis, lembar observasi keterampilan berpikir kritis.

Teknik analisis data pada pengembangan LKPD berbasis PBL ini,digunakan teknik analisis statistik deskriptif. Data yang dianalisis adalah: Analisis data kevalidan LKPD, RPP dan Tes KBK, analisis data kepraktisan LKPD, analisis data keefektifan LKPD.

\section{HASIL DAN PEMBAHASAN}

1. Hasil Penelitian

a. Proses Pengembangan LKPD Berbasis PBL

\section{b. Deskripsi Hasil Penilaian Kebutuhan} (Need Assessment)

1) Analisis Permasalahan Pembelajaran

Berdasarkan hasil telaah terhadap pelaksanaan dan hasil pembelajaran kimia di SMA Negeri 21 Makassar adalah masih rendahnya keterampilan berpikir kritis peserta didik dalam pembelajaran kimia. Sebagian besar guru masih menggunakan model dan metode yang monoton yaitu pembelajaran langsung dan ceramah. Proses pembelajaran di SMA Negeri 21 Makassar kurang melayani gaya belajar peserta didik, kurang meriah dan menyenangkan karena masih banyak guru yang tidak mau memasuki dunia peserta didik. Seperti apa yang disenangi dan diinginkan oleh peserta didik tidak menjadi pusat perhatian guru karena guru dikejar target untuk menuntaskan materi pelajarannya. Guru belum banyak mengakses perkembangan model-model pembelajaran terbaru dan penemuanpenemuan tentang cara kerja otak yang dapat memaksimalkan proses pembelajaran. Berdasarkan fenomena dilapangan diperoleh informasi sebagai berikut: (1) pembelajaran cenderung didominasi oleh guru untuk menjelaskan dengan ceramah yang mengakibatkan peserta didik lebih banyak pasif, akibatnya peserta didik kerap merasa jenuh tanpa memberi kesempatan pada peserta didik untuk terlibat aktif dalam pembelajaran. Peserta didik banyak diberikan tugas tanpa di fasilitasi dengan baik oleh guru. Banyak peserta didik yang sering mengeluh tentang cara mengajar guru yang membosankan padahal peserta didik harus menjalani hal tersebut setiap hari selama bertahun-tahun, (2) materi pembelajaran tidak dikemas menyesuaikan kondisi peserta didik, sebab berpatokan pada buku paket yang ada sehingga pembelajaran terkesan monoton dan memaksa anak untuk berbuat sesuai dengan apa yang diperintahkan guru, (3) LKPD yang dipergunakan siswa selama ini terbatas pada LKPD yang dipasarkan bebas, sehingga terkadang tidak relevan dengan perangkat pembelajaran lain yang digunakan guru dalam proses pembelajaran, dan (4) penggunaan media, alat bantu dan bahan ajar masih kurang sehingga pelajaran menjadi kurang berkesan dan bermakna.

Alternatif pemecahan masalah di atas adalah: (1) dari segi proses pembelajaran, diharapkan adanya proses pembelajaran yang menarik dan menyenangkan sehingga memudahkan peserta didik memahami suatu materi pelajaran. Pembelajaran yang berkesan dan bermakna yang dapat tersimpan dalam memori jangka panjang yang mudah diingat kembali bila dibutuhkan, dan (2) dari segi sumber pembelajaran diharapkan adanya sumber pembelajaran yang dapat digunakan untuk meningkatkan aktivitas belajar peserta didik sehingga keterampilan berpikir kritis dapat ditingkatkan.

\section{2) Analisis Peserta Didik}

Analisis ini dilakukan untuk menelaah karekteristik peserta didik yang sesuai dengan desain dan pengembangan, yang meliputi kemampuan awal peserta didik dan tingkat perkembangan kognitif. Menurut Kemp (1985) bahwa pada awal 
perencanaan sangat penting untuk memperhatikan ciri, kemampuan dan pengalaman peserta didik baik secara berkelompok maupun perorangan. Analisis peserta didik dimaksudkan untuk mengidentifikasi pengalaman belajar dan perkembangan peserta didik.

Peserta didik yang menjadi subjek penelitian ini adalah peserta didik kelas XI-IPA4 SMA Negeri 21 Makassar Semester Ganjil tahun pelajaran 2017/2018. Berdasarkan observasi siswasiswa belum terbiasa belajar berkelompok, belum menggunakan secara maksimal keterampilan berpikir kritis dalam memecahkan suatu masalah atau soal-soal yang diberikan guru pada saat pembelajaran. Bila ditanyakan tentang pelajaran waktu di SMP dulu masih sulit untuk dingat bahkan sudah dilupakan. Hal ini menunjukkan bahwa materi pelajaran yang diterima peserta didik tidak berkesan sehingga tidak tersimpan dalam memori jangka panjang.

\section{3) Analisis Tujuan Pembelajaran}

Materi pelajaran yang digunakan dalam penelitian ini adalah materi kesetimbangan kimia untuk siswa SMA kelas XI berdasarkan Kompetensi Inti dan Kompetensi Dasar. Konsep utama yang diidentifikasi pada pengembangan LKPD berbasis PBL ini adalah analisis terhadap konsep untuk materi kesetimbangan kimia. Berdasarkan analisis terhadap konsep untuk materi kesetimbangan kimia, yang mengacu pada kompetensi inti (berdasarkan Kurikulum 2013), kompetensi dasar dan indikator. Kompetensi dasar: 1) menjelaskan kesetimbangan dan faktor-faktor yang mempengaruhi pergeseran arah kesetimbangan dengan melakukan percobaan, 2) menentukan hubungan kuantitatif antara pereaksi dengan hasil reaksi dari suatu reaksi kesetimbangan, dan 3) menjelaskan penerapan prinsip kesetimbangan dalam kehidupan seharihari.
Berdasarkan KD di atas, maka pada kurikulum 2013 di SMA Negeri 21 Makassar dengan indikator sebagai berikut: (1) Menjelaskan kesetimbangan dinamis, (2) Menjelaskan kesetimbangan homogen dan heterogen, (3) Meramalkan arah pergeseran kesetimbangan dengan menggunakan azas Le Chatelier, (4) Menafsirkan data percobaan mengenai konsentrasi pereaksi dan hasil reaksi pada keadaan setimbang untuk menentukan derajat disosiasi dan tetapan Kesetimbangan, (5) Menjelaskan tetapan kesetimbangan, (6) Menghitung harga Kc berdasarkan konsentrasi zat dalam kesetimbangan, (7) menghitung harga Kp berdasarkan tekanan parsial gas pereaksi dan hasil reaksi pada keadaan setimbang, (8) Menghitung harga Kc berdasarkan Kp atau sebaliknya, dan (9) Menjelaskan kondisi optimum untuk memproduksi bahan-bahan kimia di industri yang didasarkan pada reaksi kesetimbangan.

Analisis tujuan pembelajaran disusun berdasarkan standar kompetensi sebagaimana yang tercantum dalam kurikulum 2013. Berdasarkan topik yang dipilih, rumusan tujuan pembelajaran adalah sebagai berikut: (1) Peserta didik dapat menjelaskan reaksi kesetimbangan dinamis, (2) peserta didik dapat menggolongkan reaksi kesetimbangan homogen dan heterogen, (3) peserta didik dapat menjelaskan hubungan $\mathrm{Kc}$ dan $\mathrm{Kp}$, (4) peserta didik dapat menyimpulkan arah pergeseran dari persamaan reaksi, (5) peserta didik dapat menjelaskan factor factor yang mempengaruhi pergeseran kesetimbangan, (6) peserta didik dapat menganalisis harga $\mathrm{kc}$ dan $\mathrm{Kp}$, dan (7) peserta didik dapat menganalisis hubungan tekanan parsial terhadap Kp.

\section{4) Analisis Seting Pembelajaran}

Pada analisis ini dilakukan suatu cara agar diperoleh tujuan pembelajaran yang diharapkan. Pada analisis ini, seting pembelajaran mengarahkan kepada kemampuan peserta didik untuk menjawab tugas-tugas sehingga tujuan pembelajaran 
dapat tercapai. Setiap pertemuan Peserta didik secara berkelompok mengerjakan LKPD yang berbasis PBL. Pada pertemuan pertama, kedua dan ketiga peserta didik mengerjakan LKPD yang dipadukan dengan buku siswa sebagai sumber pembelajaran. Di dalam lembar kerja peserta didik, peserta didik dituntut secara mandiri dan individual untuk mengisi lembar jawaban yang telah disediakan, kemudian peserta didik bekerja secara berkelompok dan berdiskusi untuk menyelesaikan masalah atau jawaban yang telah dikerjakan, setelah itu salah seorang peserta didik dari setiap kelompok mewakili kelompoknya mempresentasekan jawaban sebagai hasil diskusi.

\section{c. Deskripsi Hasil Desain (Design)}

Tahap ini bertujuan merancang lembar kerja peserta didik (LKPD) berbasis PBL, buku siswa dan rencana pelaksanaan pembelajaran untuk meningkatkan keterampilan berpikir kritis. Kegiatan yang dilaksanakan pada tahap ini, meliputi: penyusunan tes, pemilihan media, pemilihan format, dan rancangan (desain) awal.

\section{1) Penyusunan LKPD dan Perangkat Pendukung Pembelajaran}

Penyusunan LKPD dan perangkat pendukung pembelajaran (buku siswa, RPP dan tes KBK) terlebih dahulu dimulai dengan mengacu pada model pembelajaran berbasis masalah. Rancangan pemberian masalah pada LKPD dan buku siswa dirancang mengikuti sintaks model pembelajaran PBL yang berhubungan dengan fenomena kehidupan sehari-hari. RPP juga dirancang mengikuiti sintaks pembelajaran PBL serta dikaitkan dengan indikator atau aspek berpikir kritis dalam setiap kegiatan dalam RPP tersebut. Kemudian penyusunan tes KBK mengikuti kisis-kisi tes KBK, karena kisi-kisi tes merupakan suatu acuan atau petunjuk yang harus diikuti oleh setiap penyusunan tes keterampilan berpikir kritis. Kisi-kisi tes keterampilan berpikir kritis disusun berdasarkan spesifikasi tujuan pembelajaran, yang di dalamnya merupakan sebuah peta penyebaran butir pertanyaan yang sudah dipersiapkan sedemikian rupa sehingga dengan butir pertanyaan tersebut dapat ditentukan dengan tepat tingkat keterampilan berpikir kritis peserta didik berdasarkan spesifikasi tujuan pembelajaran. Tes keterampilan berpikir kritis ini akan diberikan kepada peserta didik sebelum dan sesudah mempelajari materi kesetimbangan kimia untuk mengetahui peningkatan keterampilan berpikir kritis peserta didik. Perangakat pembelajaran yang sudah didesain atau dirancang tersebut kemudian validasi oleh ahli, dan uji coba lapangan (uji coba terbatas).

\section{2) Pemilihan Media}

Media pembelajaran yang digunakan dalam pelaksanaan pembelajaran kimia dengan pembelajaran berbasis masalah pada materi kesetimbangan kimia adalah spidol, papan tulis dan penghapus sebagai alat presentasi bagi guru serta menggunakan media cetak berupa buku siswa dan lembar kerja peserta didik yang berbasis PBL.

\section{3) Pemilihan Format}

Format LKPD dan perangkat pendukung pembelajaran (Buku Siswa, RPP dan Tes KBK) yang digunakan disesuaikan dengan format rencana pembelajaran dalam Kurikulum 2013. Sesuai dengan prosedur kurikulm 2013, dalam rencana pelaksanaan pembelajaran tercantum kompetensi inti, kompetensi dasar, indikator, alokasi waktu, tujuan pembelajaran, materi ajar, metode pembelajaran, langkah-langkah kegiatan, alat dan sumber belajar, serta penilaian. Buku siswa yang dikembangkan untuk materi kesetimbangan kimia disajikan secara detail sesuai indikator dan tujuan pembelajaran, dan lembar kerja peserta didik yang dikembangkan sebanyak tiga LKPD yang dirancang dengan model pembelajran berbasis masalah (PBL). 
Lembar kerja peserta didik yang dikembangkan adalah satu rangkaian dengan buku siswa dibuat lebih menarik agar dapat meningkatkan keterampilan berpikir kritisnya, serta RPP yang dikembangkan juga tiga kali pertemuan yang mempunyai sintaks model pembelajaran berbasis masalah.

\section{4) Rancangan Awal}

Kegiatan utama dalam tahap akhir kegiatan perencanaan sebelum dilakukan validasi adalah penulisan LKPD berbasis PBL. Pada tahap ini juga dihasilkan rancangan awal Rencana Pelaksanaan Pembelajaran (RPP) untuk tiga kali pertemuan dan dua kali pertemuan untuk tes keterampilan berpikir kritis, dan Buku Siswa (BS), dan Lembar Kerja Peserta Didik (LKPD) untuk tiga kali pertemuan.

Buku siswa dirancang sedemikian rupa sehingga dapat membantu peserta didik memahami materi kesetimbangan kimia dan membantu dalam menyelesaikan masalah yang dalam LKPD. LKPD dirancang dalam bentuk model pembelajaran berbasis masalah sehingga pada LKPD tersebut disajikan masalah yang berhubungan dengan fenomena kehidupan sehari-hari yang mengarah materi kesetimbangan kimia serta soal-soal yang dikerjakan secara berkelompok, sehingga dapat memahami dengan lebih berkesan konsep-konsep yang ada dalam buku siswa dan LKPD tersebut, dan RPP disusun berdasarkan model pembelajaran berbasis (PBL).

\section{d. Deskripsi Hasil Tahap Pengembangan (Develop) dan Implementasi}

Tahap ini dimulai dari penilaian ahli dari LKPD dan perangkat pendukung pembelajaran (buku siswa, RPP dan tes KBK) yang telah desain yang berhubungan dengan uji validasi. Uji validasi ini dilakukan oleh validator sebanyak 2 orang. Hasil uji validasi pertama dilakukan revisi terhadap perangkat pembelajaran yang dikembangkan meliputi: (1) LKPD yang direvisi tentang isinya yang harus ditambahkan materi pembelajarannya serta materi pembelajarannya diletakkan diawal atau didepan, (2) buku siswa yang revisi tentang isinya yang harus dituliskan permasalahan yang menghubungkan dengan LKPD, (3) RPP yang revisi tentang isinya, bahwa harus dikaitkan sintaks PBL dengan indikator keterampilan berpikir kritis dalam setiap kegiatan pembelajarannya; dan (4) tes KBK yang revisi tentang kisi-kisi soalnya belum sesuai dengan aspek kognitifnya dan tidak sesuai dengan indikator pencapaian serta revisi rubrik penilaiannya yang tidak sejalan dengan indikator atau aspek KBK.

Setelah melakukan perbaikan terhadap perangkat pembelajaran selanjutnya dinilai kembali ke penilaian ahli atau validator, sehingga diperolehlah perangkat pembelajaran yang valid dari hasil pengujian kevalidan, dimana perangkat pembelajaran yang dinilai oleh ahli termasuk dalam rata-rata kategori sangat valid.

Tahap selanjutnya dari pengembangan dan implementasi ini, setelah memperoleh LKPD dan perangkat pendukung yang valid, kemudian dilakukan uji coba terbatas pada kelas XI IPA4 SMAN 21 Makassar sebanyak 35 orang untuk mengetahui tingkat kepraktisan dan keefektifan dari LKPD dan perangkat pendukung pembelajaran yang dikembangkan yang lebih utamanya yaitu LKPD karena dalam penelitian ini diarahkan untuk mengetahui peningkatan berpikir kritis dari LKPD yang dikembangkan dengan berbasis PBL. Lembaran yang digunakan untuk mengetahui kepraktisan yaitu lembar pengamatan keterlaksanaan LKPD berbasis PBL, respon guru dan lembar aktivitas guru. Serta lembaran yang digunakan untuk mengetahui keefektifan dari LKPD meliputi lembar aktivitas peserta didik dan respon peserta didik terhadap LKPD berbasis PBL yang digunakan dalam pembelajaran. Serta uji keefektifan juga untuk mengetahui 
peningkatan keterampilan berpikir kritis dari penggunakan LKPD berbasis PBL yang berhubungan dengan uji pre-test dan pos-test berpikir kritis pada materi Kesetimbangan Kimia. Adapun hasil uji analisis peningkatan keterampilan berpikir kritis dilakukan uji $N$-Gain dengan diperoleh nilai sebesar 0,824 yang berarti tinggi untuk peningkatan berpikir kritisnya peserta didik tersebut. Serta hasil observasi peserta didik dalam berpikir kritis saat pembelajaran diperoleh hasil yang sangat baik yang berarti dalam kegiatan pembelajaran tersebut peserta sudah menggunakan keterampilan berpikir kritisnya dalam menyelesaian masalah yang diberikan.

\section{Kualitas Hasil Pengembangan (Produk)}

\section{a. Analisis Data Kevalidan}

Validasi ahli dilakukan untuk melihat validitas pembelajaran, isi, dan bahasa yang mencakup semua perangkat yang dikembangkan. Hasil validasi ahli digunakan sebagai dasar untuk melakukan revisi dan penyempurnaan terhadap LKPD dan perangkat pendukung pembelajaran (RPP dan Tes KBK). LKPD dan perangkat pendukung pembelajaran hasil revisi berdasarkan masukan dari para validator ini selanjutnya diujicobakan.

Kegiatan menilai LKPD dan perangkat pendukung pembelajaran diawali dengan memberikan perangkat pembelajaran beserta lembar penilaian kepada 2 orang ahli. Hasil penilaian ahli terhadap LKPD dan perangkat pendukung dapat dilihat pada lampiran 2. Deskripsi hasil penilaian ahli terhadap LKPD dan perangkat pendukung pembelajaran sebagaimana disajikan pada Tabel 4.1.

Tabel 4.1 Deskripsi Hasil Penilaian Ahli terhadap LKPD dan Perangkat Pendukung Pembelajaran

\begin{tabular}{|l|l|c|c|}
\hline Perangkat & \multicolumn{1}{|c|}{ Indikator } & Penilaian & Kategori \\
\hline RPP & Format RPP & 3,83 & Sangat Valid \\
& Materi (isi) yang & 3,83 & Sangat Valid \\
& disajikan & 4,0 & Sangat Valid \\
& Bahasa & 4,0 & Sangat Valid \\
& Waktu & 4,0 & Sangat Valid \\
& Manfaat/Kegunaan & 4,0 & Sangat Valid \\
& RPP & & \\
Sarana dan Alat & & \\
& Bantu & & \\
& Pembelajaran & & \\
\hline \multirow{5}{*}{ RKPata-rata } & 3,94 & Sangat Valid \\
\hline & Format LKPD & 3,75 & Sangat Valid \\
& Bahasa & 4,0 & Sangat Valid \\
& Isi LKPD & 3,75 & Sangat Valid \\
& Waktu & 4,0 & Sangat Valid \\
& Manfaat/Kegunaan & 3,75 & Sangat Valid \\
& LKPD & & \\
\hline RKata-rata & 3,85 & Sangat Valid \\
\hline & Materi Soal & 3,9 & Sangat Valid \\
& Konstruksi & 3,88 & Sangat Valid \\
& Bahasa & 3,88 & Sangat Valid \\
& Waktu & 3,5 & Sangat Valid \\
\hline & Rata-rata & Sangat Valid \\
\hline
\end{tabular}

(Sumber: Lampiran 2)

Berdasarkan hasil analisis validitas

LKPD dan perangkat pendukung pembelajaran maka dapat disimpulkan bahwa LKPD dan perangkat pendukung pembelajaran dengan model pembelajaran berbasis masalah (PBL) yang terdiri dari RPP dan TKBK menurut penilaian ahli telah memenuhi kriteria kevalidan dengan kategori sangat valid.

Dari penilaian ahli diperoleh koreksi, kritik, dan saran-saran yang selanjutnya merupakan bahan pertimbangan untuk merevisi perangkat. Hasil revisi dari LKPD dan perangkat pendukung pembelajaran tersebut dapat dilihat pada lampiran 3 . Hasil validasi LKPD dan perangkat pendukung pembelajaran menunjukkan bahwa validator umumnya menyimpulkan bahwa LKPD dan perangkat pendukung pembelajaran yang dikembangkan baik dan dapat digunakan dengan melakukan sedikit revisi.

LKPD dan perangkat pendukung pembelajaran hasil revisi berdasarkan masukan dari para validator ini selanjutnya diujicobakan pada peserta didik kelas XIIPA4 SMA Negeri 21 Makassar. Uji coba dilakukan untuk melihat kepraktisan dan keefektifan LKPD dan RPP berbasis PBL yang dikembangkan. 


\section{b. Analisis Data Kepraktisan LKPD Berbasis PBL}

Data kepraktisan LKPD berbasis PBL diperoleh melalui lembar observasi keterlaksanaan LKPD berbasis PBL, lembar respon guru terhadap LKPD berbasis PBL dan lembar aktivitas guru. Hasil pengamatan keterlaksanaan LKPD berbasis PBL, respon guru terhadap LKPD berbasis PBL, dan lembar aktivitas guru, dianalisis untuk melihat tingkat kepraktisan LKPD berbasis PBL yang telah disusun dan digunakan.

Berdasarkan hasil pengamatan pada lampiran 7 diperoleh menunjukkan bahwa keterlaksanaan LKPD berbasis PBL berada pada nilai rata-rata $\mathrm{M}=1,86$ dalam kategori $(1,5 \leq \mathrm{M} \leq 2.0)$ yang artinya aspek dan kriteria yang diamati pada pelaksanaan LKPD berbasis PBL berada pada kategori terlaksana seluruhnya. Adapun yang perlu diperhatikan dalam data pengamatan ini yaitu perlunya memperhatikan alokasi waktu yang efisien dalam fase presentasi dari peserta didik yang mewakili kelompoknya karena peserta didik biasanya lambat dalam mempersiapkan diri dan jawaban yang harus dipresentasikan masih diragukan ataukah belum selesai dengan tuntas padahal biasanya siswa ingin tampil dengan sempurna.

Adapun deskripsi hasil respon guru terhadap LKPD berbasis PBL ditunjukkan pada lampiran 5. Pada lampiran 5 diperoleh bahwa presentase respon guru terhadap LKPD berbasis PBL adalah 94,76\%. Berdasarkan kriteria yang ada, dapat disimpulkan bahwa guru memberikan respon positif terhadap LKPD tersebut. Seluruh aspek yang ditanyakan dalam pelaksanaan kegiatan pembelajaran dengan menggunakan LKPD berbasis PBL mendapatkan respon positif dari guru.

Berdasarkan data hasil analisis aktivitas guru pada lampiran 14 dan 15 diperoleh bahwa semua kategori terpenuhi, yaitu kategori pertama sampai kategori ke sepuluh, karena rata-rata persentase aktivitas guru yang diamati memenuhi interval toleransi (\%) yang ditentukan. Untuk kategori kesebelas yaitu kegiatan guru di luar tugas, misalnya duduk diam di kursi, membaca koran dan sebagainya tidak teramati oleh pengamat.

Dari uraian di atas dapat disimpulkan bahwa LKPD berbasis PBL memenuhi kriteria kepraktisan yaitu lebih dari $80 \%$ memberikan respon positif dan aktivitas guru memenuhi batas toleransi yang telah ditentukan.

\section{c. Analisis Data Keefektifan LKPD Berbasis PBL}

Data kepraktisan LKPD berbasis PBL diperoleh melalui: 1) aktivitas peserta didik selama kegiatan pembelajaran memenuhi kriteria toleransi waktu yang telah ditetapkan, 2) respon peserta didik terhadap LKPD, dan 3) instrumen keterampilan berpikir kritis.

\section{1) Deskripsi Hasil Pengamatan Aktivitas Peserta Didik}

Untuk memperoleh data aktivitas peserta didik, digunakan lembar obeservasi. Pengamatan dilakukan oleh dua orang pengamat. Pengamatan aktivitas peserta didik dilakukan dengan mengamati enam orang peserta didik dengan memilih satu kelompok sebagai sampel, dengan pertimbangan bahwa kelompok tersebut mewakili semua kelompok. Prosedur pengamatan yang dilakukan adalah setiap lima menit pengamat melakukan pengamatan terhadap aktivitas peserta didik yang muncul dan mengisi lembar pengamatan yang disediakan. Hasil pengamatan aktivitas peserta didik disajikan dalam Lampiran 9.

Berdasarkan data hasil analisis aktivitas peserta didik pada uji coba, dari 8 kategori yang diamati, ada 6 kategori yang berkaitan dengan pembelajaran terpenuhi (termasuk dalam batas interval yang dapat diterima), yaitu kategori pertama sampai kategori keenam. Sedangkan kategori tujuh dan delapan yaitu kegiatan di luar tugas, misalnya tidak memperhatikan penjelasan guru, mengerjakan tugas mata pelajaran 
lain dan aktivitas lain yang tidak berkaitan dengan kegiatan pembelajaran misalnya, tidur, ngantuk, melamun dan sebagainya tidak melewati batas toleransi yang ditentukan. Artinya, kriteria pencapaian waktu ideal aktivitas peserta didik yang telah dibahas pada bab III tercapai, yaitu 6 dari 8 kategori terpenuhi dan syarat utama yaitu kategori (1), (2), (3), (4), (5) dan (6) terpenuhi. Hal ini berarti bahwa peserta didik telah melaksanakan proses pembelajaran melalui model pembelajaran berbasis masalah.

Dari uraian di atas dapat disimpulkan bahwa LKPD berbasis PBL memenuhi kriteria keefektifan yaitu aktivitas peserta didik memenuhi batas toleransi yang telah ditentukan.

\section{2) Deskripsi Data Angket Respon Peserta Didik}

Instrumen untuk memperoleh data respon peserta didik adalah angket respon peserta didik. Angket ini diberikan kepada peserta didik setelah mengikuti seluruh rangkaian kegiatan pembelajaran. Hasil analisis data respon peserta didik terhadap pelaksanaan pembelajaran yang diisi oleh 35 orang peserta didik dapat dilhat pada lampiran 5.

Berdasarkan lampiran 7 diperoleh bahwa persentase rata-rata respon peserta didik terhadap pelaksanaan kegiatan pembelajaran dengan menggunakan LKPD berbasis PBL secara keseluruhan memiliki nilai lebih besar dari 70\%. Dari keseluruhan aspek yang ditanyakan, persentase respon peserta didik terhadap pelaksanaan kegiatan pembelajaran adalah $86,77 \%$.

Dari uraian di atas dapat disimpulkan bahwa LKPD berbasis PBL memenuhi kriteria keefektifan yaitu lebih dari $70 \%$ peserta didik memberikan respon positif terhadap LKPD berbasis PBL.

\section{3) Keterampilan Berpikir Kritis \\ a) Hasil Observasi Keterampilan Berpikir Kritis}

Pengambilan data perkembangan keterampilan berpikir kritis melalui observasi. Adapun hasil obsevasi perkembangan keterampilan berpikir kritis dapat dilihat pada lampiran 15. Berdasarkan Data hasil observasi keterampilan berpikir kritis dengan skor rata-rata 3,54 menyimpulkan bahwa perkembangan keterampilan berpikir kritis peserta dari kegiatan pembelajaran dengan menggunakan LKPD berbasis PBL dalam kriteria baik sekali.

\section{b) Peningkatan Keterampilan Berpikir Kritis}

Berdasarkan analisis statistik keterampilan berpikir kritis peserta didik dengan menggunakan SPSS 16 diperoleh hasil seperti pada Tabel 4.2.

Tabel 4.2 Deskripsi Nilai Keterampilan Berpikir Kritis Siswa

\begin{tabular}{|l|c|c|}
\hline \multirow{2}{*}{\multicolumn{1}{c|}{ Statistik }} & \multicolumn{2}{|c|}{ Nilai Statistik } \\
\cline { 2 - 3 } & Pre-test & Post-test \\
\hline Jumlah peserta didik & 35 & 35 \\
Nilai terendah & 9 & 58 \\
Nilai tertinggi & 52 & 100 \\
Nilai maksimum & 100 & 100 \\
Nilai rata-rata (mean) & 28,77 & 85,17 \\
Standar deviasi & 13,40 & 12,27 \\
\hline
\end{tabular}

(Sumber: Lampiran 20)

Pada Tabel 4.3 terlihat bahwa hasil berpikir kritis dalam kategori sangat kritis pada pos-test sebanyak 21 orang dengan persentase $60,00 \%$, kategori kritis sebanyak 12 orang dengan presentase $34,28 \%$ dan kategori cukup kritis sebanyak 2 orang dengan persentase $5,72 \%$. Adapun hasil keterampilan berpikir kritis untuk pre-test, jumlah peserta didik dengan kategori sangat kritis dan kritis tidak ada, sedangkan kategori cukup kritis sebanyak 9 orang dengan persentase $25,72 \%$, dan kategori kurang kritis sebanyak 26 orang dengan presentase $74,28 \%$.

\section{Tabel 4.3 Kategori Keterampilan Berpikir Kritis Siswa Pretest dan Post- Test}




\begin{tabular}{|c|c|c|c|c|c|}
\hline \multirow[b]{2}{*}{$\begin{array}{c}\text { Kateg } \\
\text { ori }\end{array}$} & \multirow[b]{2}{*}{$\begin{array}{l}\text { Prese } \\
\text { ntase }\end{array}$} & \multicolumn{2}{|c|}{ Pre-test } & \multicolumn{2}{|c|}{ Post-Test } \\
\hline & & $\begin{array}{c}\text { Frekue } \\
\text { nsi }\end{array}$ & $\begin{array}{l}\text { Perse } \\
\text { ntase }\end{array}$ & Frekuensi & $\begin{array}{c}\text { Pers } \\
\text { enta } \\
\text { se }\end{array}$ \\
\hline $\begin{array}{c}\text { Sangat } \\
\text { kritis }\end{array}$ & $\begin{array}{ll}81,25 \\
\% & <x \\
\leq & 100 \\
\% & \end{array}$ & - & - & 21 & $\begin{array}{c}60,0 \\
0 \%\end{array}$ \\
\hline Kritis & $\begin{array}{l}62,50 \\
\% \quad<x \\
\leq \\
81,25 \\
\%\end{array}$ & - & - & 12 & $\begin{array}{c}34,2 \\
8 \%\end{array}$ \\
\hline $\begin{array}{c}\text { Cukup } \\
\text { kritis }\end{array}$ & $\begin{array}{l}43,75 \\
\%<x \\
\leq \\
62,50 \\
\%\end{array}$ & 9 & $\begin{array}{c}25,72 \\
\%\end{array}$ & 2 & $\begin{array}{c}5,72 \\
\%\end{array}$ \\
\hline$\underset{\text { kritis }}{\mathrm{g}}$ & $\begin{array}{l}25,00 \\
\% \quad<x \\
\leq \\
43,75 \\
\%\end{array}$ & 26 & $\begin{array}{c}74,28 \\
\%\end{array}$ & - & - \\
\hline \multicolumn{2}{|c|}{ Jumlah } & 35 & $100 \%$ & 35 & $\begin{array}{c}100 \\
\%\end{array}$ \\
\hline
\end{tabular}

(Sumber: Lampiran 20)

Selain data persentase kemampuan berpikir kritis siswa, juga disajikan persentase tiap aspek kemampuan berpikir kritis pada materi kesetimbangan kimia seperti terlihat pada Tabel 4.4.

Tabel 4.4 Persentase Tiap Aspek Kemampuan Berpikir Kritis

\begin{tabular}{|c|l|l|l|}
\hline \multirow{2}{*}{ No. } & Aspek Kemampuan & \multicolumn{2}{|c|}{ Presentasi Hasil } \\
\cline { 3 - 4 } Berpikir Kritis & Pretest & Post-test \\
\hline I & $\begin{array}{l}\text { Memberikan } \\
\text { penjelasan sederhana }\end{array}$ & 53,71 & 98,57 \\
2 & $\begin{array}{l}\text { Membangun } \\
\text { keterampilan dasar }\end{array}$ & 42,01 & 98,90 \\
3 & $\begin{array}{l}\text { Mengatur strategi } \\
\text { dan taktik }\end{array}$ & 21,97 & 83,68 \\
4 & $\begin{array}{l}\text { Memberikan } \\
\text { penjelasan lebih } \\
\text { lanjut } \\
5\end{array}$ & 29,13 & 83,21 \\
Menyimpulkan & 8,60 & 65,41 \\
\hline
\end{tabular}

(Sumber: Lampiran 23 dan 24)

Untuk mengetahui peningkatan keterampilan berpikr kritis maka diberikan tes berpikir kritis untuk mengukur keterampilan brepikir kritisnya sebelum dan sesudah menggunakan LKPD PBL sehingga digunakan uji gain. Adapun hasil uji gain disajikan pada Tabel 4.5.

Tabel 4.5 Hasil Uji N-Gain Keterampilan Berpikir Kritis

\begin{tabular}{|c|c|c|c|c|c|}
\hline $\begin{array}{l}\mathbf{N} \\
\mathbf{0}\end{array}$ & $\begin{array}{l}\text { Aspek } \\
\text { Berpikir } \\
\text { Kritis }\end{array}$ & Spre & Spost & $\begin{array}{l}N- \\
\text { Gai } \\
n\end{array}$ & $\begin{array}{l}\text { Katego } \\
\text { ri }\end{array}$ \\
\hline 1 & $\begin{array}{l}\text { Memberikan } \\
\text { Penjelasan } \\
\text { Sederhana }\end{array}$ & 53,71 & 98,57 & 0,97 & Tinggi \\
\hline 2 & $\begin{array}{l}\text { Membangun } \\
\text { Keterampilan } \\
\text { Dasar }\end{array}$ & 42,01 & 98,90 & 0,98 & Tinggi \\
\hline 3 & $\begin{array}{l}\text { Memberikan } \\
\text { Penjelasan } \\
\text { Lebih Lanjut }\end{array}$ & 21,97 & 83,68 & 0,79 & Tinggi \\
\hline 4 & $\begin{array}{l}\text { Mengatur } \\
\text { Strategi dan } \\
\text { Taktik }\end{array}$ & 29,13 & 83,21 & 0,76 & Tinggi \\
\hline 5 & $\begin{array}{l}\text { Menyimpulk } \\
\text { an }\end{array}$ & 8,60 & 65,41 & 0,62 & Sedang \\
\hline \multicolumn{2}{|c|}{ Rata-rata } & $\begin{array}{l}31,08 \\
4\end{array}$ & $\begin{array}{l}85,95 \\
4\end{array}$ & $\begin{array}{l}0,82 \\
4\end{array}$ & Tinggi \\
\hline
\end{tabular}

(Sumber: Lampiran 22)

Berdasarkan kriteria, didapatkan $N$ Gain sebesar 0,824 maka dapat dikatakan peningkatan keterampilan berpikir kritis dalam kategori tinggi setelah diberikan LKPD berbasis PBL pada proses pembelajarannya.

\section{Profil dari Produk LKPD Berbasis PBL}

Dalam pengembangan ini dihasilkan produk berupa LKPD berbasis PBL pada materi kesetimbangan kimia. LKPD ini disusun mulai dari sampul, kata pengantar, petunjuk penggunaan LKPD, peta konsep materi kesetimbangan kimia, $\mathrm{KI}$, KD, Indikator, kegiatan dalam LKPD mengacu pada sintaks PBL dan terdapat pula daftar pustaka dalam LKPD tersebut.

Selain itu juga dalam LKPD ini dikembangkan beberapa komponennya, yang pertama ukuran LKPD yaitu berhubungan dengan penggunaan kertas A4 dalam LKPD tersebut agar peserta didik cukup ruang dan leluasa untuk mengerjakan permasalahan yang telah disediakan. Kedua kepadatan halaman karena halaman yang terlalu pada mengakibatkan peserta didik sulit memahami bacaaan dalam LKPD, sehingga LKPD dalam penelitian ini disusunlah halamannya sebanyak 39 lembar agar peserta didik lebih mudah memahami materi kesetimbangan kimia yang disajikan. Ketiga kejelasan yang 
berhubungan dengan bahasa yang digunakan dalam LKPD tersebut mudah dipahami oleh peserta didik dan tidak menimbulkan makna ganda sehingga peserta didik akan mudah memahami isi bacaan dalam LKPD tersebut.

Serta yang keempat berhubungan topik permasalahan yang disajikan LKPD pada materi kesetimbangan kimia yang dikemas berhubungan dengan fenomena/masalah kehidupan sehari-hari agar mudah dipahami oleh peserta didik. Pemberian masalah dalam kehidupan sehari-hari ini agar peserta didik mengetahui bahwa apa terjadi yang disekitar-sekitarnya masih memiliki hubungan erat dengan proses kehidupan ini dan materi kesetimbangan kimia. Sehingga dari permasalahan tersebut dapat mengasah keterampilan berpikir kritis peserta didik.

\section{Pembahasan}

Sebagaimana telah dikemukakan sebelunya bahwa penelitian ini termasuk ke dalam jenis penelitian pengembangan (development research) yang bertujuan untuk menghasilkan buku siswa, lembar kerja peserta didik dan rencana pelaksanaan pembelajaran serta dari buku siswa dan LKPD yang dihasilkan, selanjutkan digunakan dalam pembelajaran agar dapat meningkatakn keterampilan berpikir kritis peserta didik. Selanjutnya dievaluasi oleh tim ahli untuk mendapatkan hasil yang valid, praktis dan efektif sehingga layak digunakan di sekolah-sekolah SMA.

Pada bagian ini dikemukakan pembahasan hasil penelitian mengenai ketercapaian tujuan penelitian yang meliputi tiga hal, yakni: 1) proses pengembangan LKPD berbasis PBL, 2) kualitas LKPD berbasis PBL, dan 3) peningkatan keterampilan berpikir kritis setelah menggunakan LKPD berbasis PBL dalam pembelajaran.

\section{a. Proses Pengembangan LKPD Berbasis PBL}

Proses pengembangan LKPD berbasis PBL ini menggunakan model pengembangan Hannafin \& Peck. Dimana tahapan pertama yang dilakukan dimulai dari tahap pendefenisian. Pada tahap ini dilakukan analisis permasalahan pembelajaran terhadap proses pembelajaran di sekolah. Selanjutnya dilakukan analisis peserta didik yang meliputi, latar belakang pengetahuan, perkembangan kognitif peserta didik, dan pengalaman belajar peserta didik dan analisis tujuan yang bertujuan untuk mengidentifikasi dan menyusun secara sistematis konsep-konsep utama yang berkaitan dengan materi kesetimbangan kimia. Hasil analisis tujuan digunakan untuk analisis seting pembelajaran yang berhubungan dengan proses kegiatan pembelajaran dengan menggunakan LKPD berbasis PBL sehingga dapat melatih keterampilan berpikir kritis peserta didik serta diperoleh ketercapaian tujuan pembelajaran kestimbangan kimia.

Tahap kedua adalah tahap perancangan. Pada tahap ini dilakukan penyusunan perangkat pembelajaran meliputi buku siswa, LKPD, RPP dan tes KBK dengan mengacu pada model pembelajaran berbasis masalah (PBL). Buku siswa dan LKPD berbasis PBL digunakan dalam kegiatan pembelajaran sebagai buku pemdamping guru dalam pembelajaran. RPP disusun berdasarkan sintaks model pembelajaran PBL yang dikaitkan dengan indikator atau aspek berpikir kritis dalam setiap kegiatannya. Kemudian penyusunan kisi-kisi tes Keterampilan berpikir kritis, yang telah disusun berdasarkan spesifikasi tujuan pembelajaran. Penyusunan tes ini digunakan untuk mengetahui kemampuan dan pencapaian peserta didik terhadap tujuan pembelajaran serta untuk mengetahui keterampilan berpikir kritis peserta didik karena soal yang disajikan berhubungan dengan soal berpikir kritis dan pada saat menjawabnya harus mengarah pada indikator berpikir kritis. Selanjutnya, pemilihan media yang 
diguanakan dalam proses pembelajaran yaitu menggunakan LKPD dan buku siswa serta kelengkapan lainnya. Kemudian dilakukan pemilihan format yang digunakan, disesuaikan dengan format Kurikulum 2013. Kegiatan utama dalam tahap perancangan sebelum dilakukan validasi adalah penyusunan perangkat pembelajaran berbasis PBL pada materi kesetimbangan kimia untuk SMA kelas XI yang meliputi buku siswa, lembar kerja peserta didik, rencana pelaksanaan pembelajaran, dan tes keterampilan berpikir kritis.

Tahap ketiga adalah pengembangan dan implementasi. Pada tahap in diawali dengan penilaian para ahli untuk perangkat pembelajaran yang telah dirancang yang dilakukan oleh validator sehingga diperoleh perangkat yang valid. Kemudian, dilakukan uji coba terbatas terhadap LKPD dan buku siswa agar dapat meningkatkan keterampilan berpikir kritis peserta didik yang berhubungan dengan uji kepraktisan dan keefektifan, sehingga diperoleh hasil dengan keprktisan dalam kategori praktis dan hasil uji N-Gain dari KBK sebesar 0,824 termasuk kategori tinggi, sehingga dari uji coba terbatas tersebut dihasilkan LKPD dan perangkat pendukung pembelajaran yang valid, praktis dan efektif untuk digunakan.

Hasil penelitian pengembangan ini terutama pada pengembangan LKPD, memperoleh hasil sama dengan penelitian yang dilakukan oleh Rahman, dkk (2017) dengan judul penelitian "pengembangan LKPD berbasis berpikir kritis materi kelarutan dan hasil kali kelarutan pada mata pelajaran kimia di SMA" diperoleh hasil uji kevalidan dari LKPD yang dikembangkan dengan model pengembangan Rowntree dinyatakan dalam kategori valid, kemudian untuk uji kepraktisan diperoleh hasil dalam kategori praktis karena terlihat dari kemudahan peserta didik dalam menggunakan LKPD. Serta untuk uji keefektifan termasuk dalam kategori efektif karena diperoleh hasil rata- rata $\mathrm{N}$-Gain berpikir kritis peserta didik dalam kategori sedang.

\section{b. Kualitas LKPD Berbasis PBL}

\section{1) Kevalidan}

Berdasarkan hasil penilaian dari 2 validator, menunjukkan bahwa LKPD, RPP dan Tes KBK dinyatakan sangat valid dengan sedikit revisi. Oleh karena itu dilakukan revisi berdasarkan saran para ahli dan diperoleh LKPD, RPP dan Tes KBK yang baik untuk selanjutnya diujicobakan.

Hasil analisis validasi LKPD diperoleh rata-rata $=3,85$ yang berarti sangat valid, RPP diperoleh rata-rata $=$ 3,94 yang berarti sangat valid dan TKBK diperoleh rata-rata 3,79 berarti sangat valid. Kesimpulan dari dua validator ratarata menyatakan bahwa LKPD, RPP dan TKBK yang dikembangkan dapat digunakan dengan sedikit revisi. Demikian juga instrumen lainnya berada dalam batas interval 3,5 $\leq M<4,0$ yang artinya ratarata keseluruhan komponen yang divalidasi berada pada kategori sangat valid.

Hasil uji kevalidan ini juga memperoleh kategori kevalidan yang sama dengan hasil uji kevalidan yang dilakukan oleh Rahma (2012) dengan judul penelitian "pengembangan perangkat pembelajaran model Inkuiri berpendekatan SETS materi kelarutan dan hasil kali kelarutan untuk menumbuhkan keterampilan berpikir kritis dan empati siswa terhadap lingkungan" diperoleh hasil uji kevalidan dari pengembangan perangkat pembelajaran model inkuiri berpendekatan SETS dengan menggunakan model pengembangan $3-\mathrm{D}$ termasuk dalam kategori kevalidan sangat tinggi dengan nilai sebesar 3,67.

Hasil uji kevalidan yang dilakukan juga oleh Yunianti, Hesty (2016) dengan judul penelitian "pengembangan LKPD tema pencemaran lingkungan berbasis problem based learning untuk meningkatkan keterampilan berpikir kreatif" diperoleh hasil uji kevalidan dari pengembangan LKPD berbasis PBL 
dengan menggunakan model pengembangan four-D termasuk dalam kategori kevalidan sangat tinggi dengan nilai rata-rata sebesar 3,60 dari segi isi, kebahasaan, penyajian dan kegrafikan.

\section{2) Kepraktisan}

Secara umum hasil uji coba untuk kriteria kepraktisan telah memenuhi kriteria, komponen kepraktisan LKPD ditentukan oleh dua hal, yaitu berdasarkan penilaian ahli dan praktisi, yang dinilai secara umum berdasarkan hasil pengetahuan dan pengalaman sebagai ahli dan praktisi, dan berdasarkan hasil pengamatan keterlaksanaan LKPD pada saat proses pembelajaran dilakukan dikelas, hasil respon guru terhadap LKPD berbasis PBL, dan hasil aktivitas guru selama pembelajaran.

Berdasarkan penilaian umum terhadap semua komponen yang divalidasi pada umumnya semua validator memberikan penilaian bahwa komponen yang dinilai dinyatakan dapat digunakan dengan sedikit revisi. Hasil pengamatan dua orang pengamat terhadap keterlaksanaan LKPD berbasis PBL yang telah dilaksanakan, dari hasil uji coba diperoleh hasil bahwa nilai keterlaksanaannya dapat dikatakan memadai karena semua komponenkomponen yang menjadi penilaian dalam instrumen terlaksana seluruhnya dengan tingkat realibiltas yang tinggi, dengan menunjukkan rata-rata $\mathrm{M}=1,86$ yang berada pada rentang $1,5<\mathrm{M}<2$ yang berarti terlaksana seluruhnya, sehingga LKPD berbasis PBL tersebut memenuhi kriteria kepraktisan.

Hasil respon guru terhadap LKPD berbasis PBL yaitu sebanyak empat orang, diperoleh bahwa presentase respon guru terhadap LKPD berbasis PBL adalah 94,76\%. Berdasarkan kriteria yang ada, dapat disimpulkan bahwa guru memberikan respon positif terhadap LKPD tersebut. Seluruh aspek yang ditanyakan dalam pelaksanaan kegiatan pembelajaran dengan menggunakan LKPD berbasis PBL mendapatkan respon positif dari guru. sehingga dari nilai respon tersebut terhadap LKPD berbasis PBL memenuhi kriteria kepraktisan.

Berdasarkan hasil pengamatan keterlaksanaan dan respon guru terhadap LKPD berbasis PBL, dalam menguji kepraktisan diperoleh bahwa semua komponen yang dinilai berada pada kategori terlaksana dan terespon postitif oleh guru seluruhnya karena perangkat yang digunakan pada saat pembelajaran mudah dipahami oleh peserta didik. Hal ini menunjukkan bahwa LKPD berbasis PBL yang telah dikembangkan dapat digunakan dalam pembelajaran kimia di kelas khususnya materi Kesetimbangan Kimia.

Berdasarkan hasil aktivitas guru, kriteria kepraktisan juga mengacu pada terlaksananya aktivitas guru minimal terhadap $70 \%$ aspek yang diamati. Artinya, delapan dari 11 aktivitas guru harus terlaksana.

Pada aktivitas guru, ada sepuluh kategori yang terpenuhi:

(1) Menumbuhkan motivasi melalui cerita atau presentasi hal-hal yang menarik sehubungan dengan materi yang akan dipelajari.

(2) Memberi kesempatan kepada peserta didik untuk memperoleh pengetahuan melalui kajian teori atau praktek.

(3) Mengelompokkan peserta didik dalam kelompok yang heterogen.

(4) Menjelaskan cara-cara bekerja sama dalam kelompok.

(5) Membagikan LKPD kepada peserta didik.

(6) Meminta peserta didik mengerjakan LKPD secara berkelompok.

(7) Memberi arahan dan bimbingan kepada siswa dalam mengerjakan tugas dan berdiskusi dalam kelompoknya masing-masing.

(8) Mempersilahkan salah satu wakil dari masing-masing kelompok untuk mempresentasikan hasil kerja kelompoknya. 
(9) Memberikan penguatan pada hasil diskusi

(10) Memberikan penghargaan dan merayakan pencapaian hasil belajar hari itu, dan memberi tugas.

(11) Kegiatan guru di luar tugas, misalnya duduk diam di kursi, membaca koran dan sebagainya.

Selama kegiatan pembelajaran dengan LKPD berbasis PBL pada materi kesetimbangan kimia, guru melakukan kegiatan sesuai sintaks PBL sehingga membuat peserta didik terlibat aktif dan dominasi guru dalam pembelajaran dapat dikurangi. Dengan demikian dapat disimpulkan bahwa LKPD berbasis PBL dapat mengoptimalkan peserta didik dalam pembelajaran sehingga lebih mandiri.

Hasil penelitian pengembangan ini juga memperoleh kategori kevalidan dan kepraktisan yang mirip dengan hasil penelitian yang dilakukan oleh Andromeda, dkk (2017) dengan judul penelitian "pengembangan lembaran kerja siswa (LKS) eksperimen berbasis GuidedInquiry materi laju reaksi untuk siswa SMA/MA" diperoleh hasil uji kevalidan dan kepraktisan dari pengembangan LKS eksperimen berbasis guided inquiry dengan menggunakan model pengembangan fourD termasuk dalam kategori kevalidan sangat tinggi dan dan kepraktisan tinggi.

\section{3) Keefektifan}

Kriteria keefektifan perangkat pembelajaran meliputi: (1) aktivitas peserta didik, (2) respon peserta didik, dan (3) peningkatan keterampilan berpikir kritis. Hasil analisis data untuk keefektifan LKPD berbasis PBL yang digunakan adalah sebagai berikut:

\section{a) Aktivitas Peserta Didik}

Kriteria keefektifan selanjutnya adalah terlaksananya aktivitas peserta didik minimal terhadap $70 \%$ aspek yang diamati. Hal ini berarti dari 8 aktivitas peserta didik yang diamati, 6 diantaranya harus terlaksana. Berdasarkan hasil analisis data aktivitas peserta didik menunjukkan bahwa delapan kategori pada aktivitas peserta didik terpenuhi yaitu:

(1) Mendengarkan cerita atau presentasi yang disajikan guru untuk memberikan motivasi

(2) Mengikuti pelajaran dengan kajian teoritis maupun praktek yang difasilitasi oleh guru

(3) Aktif terlibat dalam mengerjakan atau menyelesaikan permasalahan yang ada dalam LKPD

(4) Aktif berdiskusi dengan teman kelompoknya masing-masing

(5) Melakukan presentasi hasil kerja kelompok

(6) Menjawab/menanggapi pertanyaan kuis

(7) Kegiatan di luar tugas, misalnya tidak memperhatikan penjelasan guru, mengerjakan tugas mata pelajaran lain.

(8) Aktivitas lain yang tidak berkaitan dengan kegiatan belajar mengajar misalnya, tidur, ngantuk, melamun dan sebagainya.

Selama kegiatan pembelajaran dengan LKPD berbasis PBL pada materi kesetimbangan kimia, peserta didik terlibat aktif sehingga dominasi guru dalam pembelajaran dapat dikurangi. Dengan demikian dapat disimpulkan bahwa LKPD berbasis PBL dapat mengoptimalkan peserta didik dalam pembelajaran sehingga lebih mandiri.

\section{b) Respon Peserta Didik}

Dari hasil analisis diperoleh bahwa seluruh aspek yang dinyatakan dalam pelaksanaan pembelajaran dengan menggunakan LKPD berbasis PBL mendapatkan respon positif dari peserta didik. Hal ini berarti peserta didik tertarik secara tertulis untuk menggunakan LKPD berbasis PBL, serta berminat untuk mengikuti pembelajaran dengan model pembelajaran berbasis masalah (PBL) karena model pembelajaran tersebut peserta didik akan lebih tertantang untuk menyelesaiakan permasalahan sehingga 
peserta didik akan lebih memahami materi yang disajikan.

Berdasarkan hasil analisis respon siswa terhadap LKPD diperoleh bahwa $86,77 \%$ peserta didik memberikan respon positif. Dengan demikian dapat disimpulkan bahwa LKPD berbasis PBL dapat mengarahkan peserta didikdalam belajar dan mencapai tujuan yang diinginkan.

Dari hasil analisis dan pembahasan, dapat disimpulkan bahwa lembar kerja peserta didik dan rencana pelaksanaan pembelajaran telah memenuhi kriteria valid, praktis dan efektif.

\section{c) Peningkatan Keterampilan Berpikir Kritis}

\begin{tabular}{lcrr}
\multicolumn{2}{c}{ Berdasarkan } & deskripsi & data \\
kemampuan & berpikir & kritis & siswa \\
menunjukkan & gambaran & umum
\end{tabular} kemampuan berpikir kritis siswa baik pada sebelum dan sesudah pembelajaran. Pada Tabel 4.9 terlihat bahwa nilai tertinggi seudah diberi pembelajaran lebih besar daripada sebelum diberi pembelajaran yaitu 100 untuk sesudah pembelajaran dan 90 untuk sebelum pembelajaran. Selain nilai tertinggi, nilai rata-rata sesudah pembelajaran juga lebih besar, yaitu 65,56 sedangkan sebelum pembelajaran sebesar 57,50. Hasil tersebut menunjukkan bahwa nilai rata-rata siswa sesudah pembelajaran dengan LKPD berbasis PBL lebih tinggi daripada sebelum pembelajaran dengan selisih 56,40 poin. Lebih besarnya sesudah pembelajaran dengan LKPD berbasis PBL menunjukkan bahwa keterampilan berpikir kritis peserta didik sesudah pembelajaran lebih baik daripada sebelum pembelajaran. Hasil posttest dan pretest yang mewakili 5 aspek berpikir kritis yang terdiri dari beberapa sub indikator yang ada di dalamnya pada hasil post-test diperoleh rata-rata keterampilan berpikir kritisnya lebih tinggi daripada pretest.

Indikator berpikir kritis yang pertama yaitu memberikan penjelasan sederhana, data yang diperoleh dari posttest sebesar $98,57 \%$ sedangkan pada pretest sebesar $53,71 \%$. Indikator berpikir kritis yang kedua yaitu membangun keterampilan dasar, data yang diperoleh pada posttest sebesar $98,90 \%$ sedangkan pada kelas pretest sebesar 42,01\%. Indikator berpikir kritis yang ketiga yaitu memberikan penjelasan lebih lanjut, data yang diperoleh dari posttest sebesar $83,68 \%$ sedangkan pada pretest sebesar $21,97 \%$. Indikator berpikir kritis yang keempat yaitu mengatur strategi dan taktik, data yang diperoleh pada kelas eksperimen sebesar $83,21 \%$ sedangkan pada pretest sebesar $29,13 \%$. Indikator berpikir kritis yang kelima yaitu menyimpulkan, data yang diperoleh pada posttest sebesar $65,41 \%$ sedangkan pada pretest sebesar $8,60 \%$.

Pada indikator berpikir kritis yang kelima ini pada posttest yang diperoleh nilai presentase tergolong rendah karena kebanyakan peserta didik tidak menjawab semua soalnya dan kalaupun menjawab semua namun hasil perhitungannya salah sehingga pada saat menyimpulkan menjadi salah pula, pada instrument penelitian terdiri dari sebagian besar soal perhitungan dimana pembelajaran yang dilaksanakan lebih mengarah kepada konsep-konsep. Pembelajaran dengan konsep-konsep tersebut menyebabkan kurangnya contohcontoh utamanya pada soal perhitungan sehingga mempengaruhi kemampuan berpikir kritis siswa, serta sebelum menyimpulkan suatu permasalahan atau soal harus mengatur strategi dan taktik yang baik dan benar-benar matang agar menghasilkan kesimpulan yang baik dan benar. Tapi secara keseluruhan diperoleh keterampilan berpikir kritis peserta didik mengalami peningkatan yang terlihat dari presentase rata-rata tiap aspek ketermpilan berpikir kritis mengalami kenaikan.

Berdasarkan Tabel 4.8 dapat dilihat bahwa presentasi rata-rata untuk setiap aspek berpikir kritis mengalami peningkatan untuk sesudah pembelajaran dan terlihat juga dari presentasi rata-rata uji N-gain untuk ketrampilan berpikir kritis sebesar 0,824. Hasil ini menunjukkan 
bahwa secara keseluruhan terjadi peningkatan untuk keterampilan berpikir kritis setelah diberikan LKPD berbasis PBL. serta menunjukkan bahwa LKPD berbasis PBL membuat peserta didik mejadi lebih mandiri sehingga bisa mengasah keterampilan berpikirnya terutama berpikir kritis.

Berdasarkan lampiran 15 diperoleh bahwa persentase hasil observasi keterampilan berpikir kritis setiap indikator tidak mencapai $100 \%$, walaupun begitu aktivitas peserta didik pada setiap pertemuan yang semakin meningkat ini yang dilihat dari data observasi keterampilan berpikir kritisnya pada tabel 4.12 yang memperlihatkan antusias peserta didik yang semakin meningkat dalam kegiatan pembelajaran yang dilaksanakan.

Hasil uji peningkatan keterampilan berpikir kritis yang dilakukan oleh Rahma (2012) dengan judul penelitian "pengembangan perangkat pembelajaran model Inkuiri berpendekatan SETS materi kelarutan dan hasil kali kelarutan untuk menumbuhkan keterampilan berpikir kritis dan empati siswa terhadap lingkungan" diperoleh hasil uji $\mathrm{N}$-Gain keterampilan berpikir kritis dari pengembangan perangkat pembelajaran model inkuiri berpendekatan SETS dengan menggunakan model pengembangan 3-D termasuk dalam kategori tinggi dengan nilai $\mathrm{N}-$ Gain sebesar 0,72 .

Hasil uji peningkatan keterampilan berpikir kritis yang dilakukan juga oleh Wahyuni, Sri (2015) dengan judul penelitian "pengembangan bahan ajar IPA untuk meningkatkan kemampuan berpikir kritis siswa SMP" diperoleh hasil keterampilan berpikir kritis dari pengembangan bahan ajar dengan menggunakan model pengembangan 4-D menunjukan peningkatan KBK baik yang dimabil dengan teknik tes maupun pratikum. Berdasarkan dari teknik tes diperoleh hasil $75 \%$ peserta didik memiliki kemampuan berpikir kritis dan 7,5\% memiliki kemampuan sangat kritis.
Kemudian hasil uji keefektifan yang dilakukan oleh Khotim, dkk (2015) dengan judul penelitian "pengembangan modul kimia berbasis masalah pada materi asam basa" diperoleh hasil uji N-Gain hasil belajar peserta didik dari pengembangan modul berbasis masalah dengan menggunakan model 3-D termasuk dalam kategori sedang dengan nilai N-Gain sebesar 0,41 .

Hasil penelitian lainnya yang berhubungan dengan uji kefektifan yang dilakukan oleh Alfana, dkk (2015) dengan judul penelitian "pengembangan lembar kegiatan siswa IPA terpadu berbasis konstruktivisme tema energi dalam kehidupan untuk siswa SMP" diperoleh hasil uji N-Gain hasil belajar dan kemampuan berpikir kreatif peserta didik dari pengembangan LKS berbasis konstruktivisme dengan menggunakan model pengembangan 4-D termasuk dalam kategori sedang dengan nilai $\mathrm{N}$-Gain sebesar 0,52.

\section{Karakteristik Lembar Kerja Peserta Didik (LKPD) Berbasis PBL}

Produk yang dikembangkan dari penelitian ini adalah LKPD pada materi Kesetimbangan Kimia untuk kelas XI IPA SMA/MA semester ganjil dengan model pengembangan Hannafin \& Peck. LKPD berisi 39 halaman disusun berdasarkan pembelajaran berbasis masalah (PBL) yaitu suatu pembelajaran yang menyajikan masalah yang berhubungan dengan fenomena kehidupan sehari-hari atau kontekstual pada materi kesetimbangan kimia, sehingga dapat menuntun peserta didik untuk menemukan sendiri konsep kimia yang sedang dipelajarinya dari permasalahan yang disajikan.

LKPD dimulai dengan memberikan permasalahan berkaitan materi kesetimbangan kimia sebagai umpan yang mengarah pada materi, diskusi, serta evaluasi berupa contoh soal bertujuan untuk mengasah kemampuan berpikir kritis dan kepahaman peserta didik. Materi yang disajikan dalam LKPD berbasis PBL 
adalah kesetimbangan kimia yang meliputi sub materi kesetimbangan dinamis, jenisjenis reaksi kesetimbangan, pergeseran kesetimbangan, Kc dan Kp serta hubungan harga $\mathrm{Kc}$ dan $\mathrm{Kp}$ dalam suatu reaksi kesetimbangan.

Penampilan LKPD dibuat secara menarik dengan halaman judul menggunakan ilustrasi yang berkaitan materi Kesetimbangan Kimia. Judul LKPD ini adalah "LKPD Berbasis PBL Kesetimbangan Kimia". Desain cover menggunakan perpaduan berbagai warna yang cerah dan menarik. Gambar dengan berbagai warna cerah akan lebih menarik dan membangkitkan minat serta perhatian siswa (Anitah, 2008). LKPD dicetak dengan menggunakan kertas ukuran A4, dimaksudkan agar siswa mudah dalam menggunakannya. Hal tersebut sesuai pernyataan Prastowo (2014), LKPD sebaiknya menggunakan ukuran kertas yang dapat mengakomodasi kebutuhan pembelajaran. Sub judul yang ada pada LKPD dituliskan dengan font yang lebih besar. Arsyad (2009), huruf yang dicetak tebal atau miring memberikan penekanan pada kata kunci atau judul serta warna berbeda digunakan sebagai alat penuntun dan penarik perhatian untuk informasi yang penting.

LKPD ini disusun dengan mengintegrasikan kemampuan berpikir kritis dengan pembelajaran berbasis masalah. Pada awal pembelajaran, guru menyajikan berbagai topik permasalahan kesetimbangan kimia yang berhubungan dengan fenomena kehidupan sehari-hari sebagai permasalahan yang harus dipecahkan, tujuannya agar siswa termotivasi untuk terlibat aktif dalam kegiatan pemecahan masalah. Penyajian masalah membuat siswa berpikir dan mengasumsi penyelesaian masalah dari pengalaman yang pernah dialami. Guru membimbing peserta didik dalam proses pengumpulan informasi secara berkelompok untuk mendapatkan solusi dari permasalahan yang dihadirkan pada awal pembelajaran, kemudian menganalisis hasilnya sesuai dengan teori yang ada.

Tahap terakhir dalam pembelajaran berbasis masalah, mengevaluasi hasil penyelidikan bersama kelompok dan mempresentasikan di depan kelas. Pada tahap akhir ini, guru membantu peserta didik untuk melakukan refleksi atau evaluasi terhadap penganalisisan masalah yang telah dilakukan apabila ada perbedaan konsep kimia. Intruksi dalam kegiatan diskusi dapat keterampilan berpikir kritis siswa melalui penganalisisan suatu masalah (Hassoubah, 2004).

Hasil penelitian pengembangan bahan ajar ini memiliki hasil yang sama dengan penelitian yang dilakukan oleh Taslim, dkk (2017) dengan judul penelitian "pengembangan buku teks pelajaran IPA terintegrasi mitigasi bencana pada bahasan getaran dan gelompang" diperoleh hasil uji kevalidan terhadap buku teks IPA yang dikembangkan meliputi; ukuran dan isi produk (kulit dan isi buku) dengan menggunakan model pengembangan Hannafin \& Peck termasuk dalam kategori valid dengan nilai rata-rata 4,04, serta mendapat respon positif dari peserta didik terhadap buku teks tersebut dengan nilai presentase rata-rata sebesar $95,9 \%$.

Hasil penelitian lainnya yang dilakukan oleh Ananda dan Azizah (2016) dengan judul penelitian "pengembangan LKS berorientasi problem based learning untuk melatihkan creative thinking skill pada materi kesetimbangan kimia" diperoleh hasil uji validasi terhadap LKS yang dikembangkan meliputi; validasi isi, penyajian, kegrafikan, dan kebahasaan dengan menggunakan model pengembangan 4-D termasuk dalam kategori rata-rata valid dengan nilai persentase rata-rata $87,725 \%$. Serta LKS tersebut juga mampu melatihkan creative thinking skill peserta didik karena tercermin dari aktivitas berpikir kreatif peserta didik mengalami peningkatan dalam setiap pertemuannya dalam LKS tersebut. 
Hasil penelitian yang dilakukan juga oleh Nofiyanti dan Ismono (2015) dengan judul penelitian "pengembangan lembar kegiatan siswa berorientasi problem based instruction (PBI) untuk melatihkan keterampilan berpikir kritis siswa pada materi pokok laju reaksi siswa kelas XI SMAN 15 Surabaya" diperoleh hasil uji validasi terhadap LKS yang dikembangkan meliputi; validasi materi, bahasa, penyajian, kesesuaian dengan PBI, dan kesesuaian dengan komponen berpikir kritis dengan menggunakan model pengembangan 4-D termasuk dalam kategori rata-rata sangat valid dengan nilai persentase rata-rata $99,78 \%$. Serta LKS tersebut juga mampu melatihkan ketrampilan berpikir kritis peserta didik termasuk kategori terlatih dengan nilai rata-rata mencangkup semua aspek KBK sebesar 73,75.

\section{KESIMPULAN}

Berdasarkan hasil penelitian yang telah diuraikan, dapat disimpulkan sebagai berikut.

1. Proses pengembangan LKPD berbasis PBL mengacu pada model Hannafin \& Peck, meliputi: 1) tahap penilaian kebutuhan yang terdiri dari empat langkah yaitu: analisis permasalahan pembelajaran, analisis peserta didik, analisis tujuan, dan analisis seting pembelajaran, 2) tahap desain yang terdiri dari empat langkah, yaitu: penyusunan LKPD dan perangkat pendukung pembelajaran, pemilihan media, pemilihan format, dan desain/rancangan awal. 3) tahap pengembangan, dan implementasi yakni penilaian ahli dan uji coba terbatas di SMA Negeri 21 Makassar. Selanjutnya semua desain awal divalidasi oleh ahli, dan berada pada kategori sangat valid, kemudian diujicobakan untuk mengetahui kepraktisan dan keefektifan, sehingga layak digunakan sebagai sumber pembelajaran dan pendamping guru.
2. Kualitas LKPD berbasis PBL yakni: 1) sangat valid berdasarkan penilaian oleh ahli dengan sedikit revisi, 2) praktis karena seluruh aspek pembelajaran dapat terlaksana, mendapat respon positif dari guru dan aktivitas guru berada pada interval toleransi, dan 3) efektif karena aktivitas peserta didik berada pada batas interval toleransi, dan respon peserta didik terhadap LKPD berbasis PBL mendapatkan respon positif, serta efektif dalam meningkatkan keterampilan berpikir kritis peserta didik.

3. LKPD berbasis PBL ini dapat meningkatkan keterampilan berpikir kritis peserta didik karena diperoleh hasil analisis uji N-Gain sebesar 0,824 dengan kategori tinggi.

\section{DAFTAR PUSTAKA}

Alfana, Mila, dkk. 2015. Pengembangan Lembar Kegiatan Siswa IPA Terpadu Berbasis Konstruktivisme Tema Energi Dalam Kehidupan Untuk Siswa SMP. Unnes Science Education Journal ISSN 2252-6617, Universitas Negeri Semarang, diakses pada tanggal 15 Februari 2018 di Makassar.

Ananda, Putri, Mega dan Azizah, Utlya. 2016. Pengembangan LKS Berorientasi Problem Based Learning Untuk Melatihkan Creative Thinking Skill Pada Materi Kesetimbangan Kimia. Unesa Journal of Chemistry Education Vol 5, No 2, pp. 224-232 Mei 2016, ISSN 2252-9454, Universitas Negeri Semarang, diakses pada tanggal 15 Februari 2018 di Makassar.

Anderson, J.A. 2003. Critical Thinking Across the Discplines. New York: Makalah Pada Faculty Development Seminar in New York City College of Technology.

Andromeda, dkk. 2017. Pengembangan Lembaran Kerja Siswa (LKS) 
Eksperimen Berbasis Guided-Inquiry Materi Laju Reaksi Untuk Siswa SMA/MA. Jurnal Eksakta Pendidikan (JEP) Volume 1 Nomor 1 Mei 2017 e-ISSN 2579-860X, Universitas Negeri Padang, diakses pada tanggal 15 Februari 2018 di Makassar.

Anitah S. 2008. Media Pembelajaran. Surakata: LPP UNS dan UNS Press.

Arikunto, S. 2007. Dasar- Dasar Evaluasi Pendidikan. Ed.Revisi, Cet.7. Jakarta: Rineka Cipta.

Arsyad, azhar. 2006. Media pembelajaran. Jakarta: PT. Raja Grafindo.

Aprida, Irlani, Delima, Sari. 2017. Pengembangan LKPD Berbasis Problem Based Learning Untuk meningkatkan kemampuan Berpikir kritis Pada Pembelajaran Tematik Peserta Didik Kelas IV Sekolah Dasar. Bandar Lampung: Program Magister Keguruan Guru Sekolah Dasar, FKIP Universitas Lampung.

Azmi, Choirina, Unik. 2011. Pengaruh Model Pembelajaran Inkuiri dengan Pendekatan Pictorial Riddle terhadap Kemampuan Berpikir Kritis Siswa. Semarang: Skripsi, Program Studi Pendidikan Fisika, Fakultas Pendidikan Matematika dan Ilmu Pengetahuan Alam, IKIP PGRI Semarang.

Brooks, J.G. \& Brooks, M.G. 1999. In search of understanding: The Case for Constructivist Classrooms. Alexandria, VA: Association for Supervision and Curriculum Development.

http://asimov.coehs.uwosh.edu/ cra mer/case study1/Concepts/ Constructivist.html. Diakses pada tanggal 27 Juli 2017 di Makassar.

Damayanti, D.S., Nur N., \& Eko S.K. 2013. Pengembangan Lembar Kerja Siswa (LKS) Dengan Pendekatan Inkuiri Terbimbing Untuk Mengoptimalkan Kemampuan Berpikir Kritis Siswa Pada Materi Listrik Dinamis SMA Negeri 3
Purworejo Kelas X Tahun Pelajaran 2012/2013. Purwokerto.

Darmojo, H., \& Kaligis, J. R.E.. 1993. Pendidikan IPA II. Jakarta: Depdikbud.

Delisle, R. 1997. How to Use ProblemBased Learning in the Classroom. Virginia: Association for Supervision and Curriculum Development.

Departemen Pendidikan Nasional. 2003. Kurikulum 2004 Standar Kompetensi Mata Pelajaran Matematika SMP. Jakarta.

Depdiknas. 2008. Panduan Pengembangan Bahan Ajar. Jakarta: Departemen Pendidikan Nasional Direktorat Pendidikan Dasar dan Menengah.

Depdiknas. 2004. Pedoman Penyusunan Lembar Kegiatan Siswa dan Skenario Pembelajaran Sekolah Menengah Atas. Jakarta: Depdiknas Direktorat Pembinaan Sekolah Menengah Atas.

Dwijananti, P., D. Yulianti. 2010. Pengembangan Kemampuan Berpikir Kritis Mahasiswa Melalui Pembelajaran Problem Based Instruction Pada Mata Kuliah Fisika Lingkungan. Jurnal Pendidikan Fisika Indonesia, 6: 108- 114.

Eni, Wiwin Maryanti. 2016. Pengembangan LKPD dengan Model Problem Based Learning untuk Mengembangkan Kemampuan Berpikir Kritis dan Dispososi Berpikir Kritis. Program Pascasarjana Magister Pendidikan Matematika, FKIP, Universiatas Lampung. Bandar Lampung.

Ennis, R. H. (1987). A Taxonomy of Critical Thinking Dispositions And Abilities. In J. B. Baron \& R. J. Sternberg (Eds.), Series of books in psychology. Teaching thinking skills: Theory and practice (pp. 926). New York: W H Freeman/Times Books/ Henry Holt \& Co.

Ennis, R.H. (2002). "An Outline of Goals for a Critical Thinking Curriculum and Its Assessment". This is a revised 
version of a presentation at the Sixth International Conference on Thinking at MIT, Cambridge, MA, July, 1994. http://www.criticalthinking.net/goals. html. Diakses pada tanggal 27 Juli 2017 di Makassar.

Fauziah, Resti, dkk. 2013. Pembelajaran Saintifik Elektronika Dasar Berorientasi Pembelajaran Berbasis Masalah. Bandung: Jurnal pembelajaran saintifik, volume IX, No. 2 166-168.

Hake, Richard R. 1999. Analyzing Change/Gain Scores. Departhement of Physics, Indiana University 24245 Hanteras Street, Woodland Hills, CA, 91367 USA.

Hasruddin. 2009. Memaksimalkan Kemampuan Berpikir Kritis Melalui Pendekatan Kontekstual. Jurnal Tabularasa Pps Unimed, 6(1): 4960.

Hassoubah, Z.I. 2014. Cara Berpikir Kreatif dan Kritis. Translated by Bambang Suryadi. Bandung: Penerbit Nusantara.

Herman, T. 2007. Pembelajaran berbasis Masalah untuk meningkatkan Kemampuan berpikir matematika tingkat tinggi siswa sekolah menengah pertama. Bandung: Disertasi pada PPs UPI.

Hernawan, Herry, Asep. 2008. Pengembangan Kurikulum dan Pembelajaran Jakarta: Universitas Terbuka.

Hmelo-Silver, C. E., \& Barrows, H. S. 2006. Goals and Strategies of A Problem-Based Learning Facilitator, Interdisciplinary Journal of Problembased Learning.

Hobri. 2009. Metodologi Penelitian Pengembangan [Aplikasi Pada penelitian Pendidikan Matematika]. Jember : Pena Salsabila.

Hung, W., Jonassen, D. H., \& Liu, R. 2014. A Problem-based Ubiquitous Learning Approach to Improving the Questioning Abilities of Elementary
School Students. In J. M. Spector, J. G. VanMerriënboer, M. D., Merrill, \& M. Driscoll (Eds.), Handbook of research on educational communicationsand technology (3rd ed., pp. 485-506). Mahwah, NJ. Erlbaum.

Humasah, \& Yanur S. 2013. Desain Pembelajaran Berbasis Pencapaian Kompetensi. Jakarta: Prestasi Pustaksa Raya.

Irmayanti. 2015. Pengaruh Penilaian Portofolio dalam Model Pembelajaran Advanced Organizer dan Kemampuan Awal terhadap Pemahaman Konsep dan Motivasi Belajar Kimia Peserta didik kelas XI SMA Negeri 12 Makassar. Program Pascasarjana Universitas Negeri Makassar.

Kadhafi, Rizky. 2013. Pengembangan Modul Kesetimbangan Kimia Berbasis Inkuiri Terbimbing (Guided Inquiry) Untuk SMK. Malang: Universitas Negeri Malang.

Kalsum, Siti, dkk. 2009. Kimia 2 Kelas XI SMA dan MA. Jakarta: Pusat Perbukuan.

Kemp, J. E, Dayton. 1985. Planing and Producing Instructional Media. Harper \& Row, New york.

Khalaliyah, Rizki. 2015. Pengembangan Lembar Kerja Siswa (LKS) Berbasis Pendekatan Problem Solving Untuk Meningktakan Berpikir Kritis Siswa Pada Materi Alat Optik. Jurusan Fisika FMIPA Universitas Negeri Semarang.

Khotim, Hikmatun, Nurul, dkk. 2015. Pengembangan Modul Kimia Berbasis Masalah Pada Materi Asam Basa. Jurnal Chemistry in Education ISSN No 2252-6609, Universitas Negeri Semarang, diakses pada tanggal 15 Februari 2018 di Makassar.

Majid, Abdul. 2011. Perencanaan Pembelajaran. Bandung: PT. Remaja Rosdakarya 
Nofiyanti, Dwi, Wigati dan Ismono. 2015. Pengembangan Lembar Kegiatan Siswa Berorientasi Problem Based Instruction (PBI) Untuk Melatihkan Keterampilan Berpikir Kritis Siswa Pada Materi Pokok Laju Reaksi Siswa Kelas XI SMAN 15 Surabaya. UNESA Journal of Chemical Education Vol.4, No.2, pp.172-179, May 2015, ISSN 2252-9454, Universitas Negeri Semarang, diakses pada tanggal 15 Februari 2018 di Makassar.

Nurdin. 2007. Model Pembelajaran Matematika yang Menumbuhkan Kemampuan Metakognitif untuk Menguasai Bahan Ajar. Surabaya: UNESA

Nurhadi. 2004. Pembelajaran Kontekstual (Contextual Teaching and Learning/ CTL) dan Penerapannya dalam $K B K$. Malang: Penerbit UM.

PPs UNM. 2012. Pedoman Penulisan tesis dan Disertasi Program Pascasarjana UNM Makassar. Makassar: PPs UNM.

Prastowo, Andi. 2011. Bahan Ajar Inovatif. Yogjakarta: DIVA Press.

Prastowo, Andi. 2011. Metode Penelitian Kualitatif dalam Perspektif Rancangan Penelitian. Jogjakarta: Ar-Ruzz Media.

Rahardian, Dewi, Titah. 2011. Metode The King Kimia Ala Tentor. Jakarta: Wahyumedia.

Rachman, Fuad Abdul, dkk. 2017. Pengembangan LKPD Berbasis Berpikir Kritis Materi Kelarutan Dan Hasil Kali Kelarutan Pada Mata Pelajaran Kimia Di SMA. Jurnal Alkimia Vol.1 No.1 2017, UIN Raden Fatah Palembang, diakses pada tanggal 15 Februari 2018 di Makassar.

Rahma, Alifa Noora. 2012. Pengembangan Perangkat Pembelajaran Model Inkuiri Berpendekatan SETS Materi Kelarutan Dan Hasil Kali Kelarutan Untuk Menumbuhkan Keterampilan Berpikir Kritis Dan Empati Siswa
Terhadap Lingkungan. Journal of Education Research and Ealuation ISSN 2252-6420, Universitas Negeri Semarang, diakses pada tanggal 15 Februari 2018 di Makassar.

Riduwan, 2010. Metode dan Teknis Menyusun Tesis. Bandung : Alfabeta

Riyanto, Yatim. 2009. Paradigma Baru Pembelajaran. Jakarta: Kencana Prenada.

Rohaeti, E., LFX, E. Wijayanti., \& Padmaningrum, R. T. 2009. Pengembangan Lembar Kerja Siswa (LKS) mata pelajaran sains kimia untuk SMP. Jurnal Inovasi Pendidikan, 10(1).

Rosmaini. 2009. Keterbacaan Buku Teks. Medan: FBS UNIMED.

Rusman. 2010. Model- Model Pembelajaran. Jakarta: Raja Grafindo Persada.

Rusmono. 2012. Srategi Pembelajaran dengan Problem Based Learning Itu perlu. Jakarta: Ghalia Indonesia.

Savinainen, A. 2004. High School Students Conceptual Coherence of Qualitative Knowledge in the Case of the Force Concept. Dissertation, University of Joensuu.

Sobihi, Muh dan Siswanto, joko. 2012. Pengaruh Pembelajaran Berbasis Masalah Dan Inkuiri Terbimbing Terhadap Kemampuan Berpikir Kritis Dan Kreatif Siswa. Semarang: Prodi Pendidikan Fisika, IKIP PGRI Semarang.

Sudjana, nana. 2010. Penilaian hasil dan Proses belajar Mengajar. Bandung: Remaja Rosdakarya.

Sudijono, Anas. 2011. Pengantar Evaluasi Pendidikan. Jakarta: Raja Grafindo Persada.

Sugiyono. 2009. Metode Penelitian Kuantitatif, Kualitatif, dan $R \& D$. Bandung: Alfabeta.

Sugiyono. 2010. Metode Penelitian Pendidikan: Pendekatan Kualitatif, Kuantitatif, dan R\&D. Bandung: Alfabeta. 
Sugiyono. 2013. Metode Penelitian Pendidikan Pendekatan Kuantitatif Kualitatif dan $R \quad \& D$. Bandung: Alfabeta.

Suryana, I Made, dkk. 2014. Pengembangan Bahan Ajar Cetak Menggunakan Model Hannafin \& Peck Untuk Mata Pelajaran Rencana Anggaran Biaya. e-Juornal Program Pascasarjana Universitas Pendidikan Ganesha Program, Studi Teknologi Pembelajaran, Volume 4 tahun 2014, diakses pada tanggal 10 Oktober 2017 di Makassar.

Suyanto, Eko dan Sartinem. 2009. Pengembangan Contoh Lembar Kerja Fisika Siswa dengan Latar Penuntasan Bekal Awal Ajar Tugas Studi Pustaka dan Keterampilan Proses untuk SMA Negeri 3 Bandar Lampung. Bandar Lampung: Prosiding Seminar Nasional Pendidikan 2009. Unila.

Taslim, Rhoshandhayani, Koesiyanto, dkk. 2017. pengembangan buku teks pelajaran IPA terintegrasi mitigasi bencana pada bahasan getaran dan gelompang. Jurnal Seminar Nasional Pendidikan Fisika 2017, ISSN 25275917, vol.2, Universitas Jember, diakses pada tanggal 15 Februari 2018 di Makassar.

Tegeh, I Made, dkk. 2014. Model Penelitian Pengembangan. Yogyakarta: Graha Ilmu.

Trianto. 2007. Model pembelajaran Terpadu dalam Teori dan Praktek. Jakarta: Prestasi Pustaka.

Trianto. 2011. Model-Model Pembelajaran Inovatif

Berorientasi

Konstruktivistik. Jakarta: Prestasi Pustaka.

Wahyuni, Sri. 2015. Pengembangan bahan Ajar IPA untuk meningkatkan kemampuan berpikir kritis siswa $S M P$. Jurnal materi dan pembelajaran fisiska, Volume 5 nomor 22015 ISSN: 2089-6158, Universitas Jember, diakses pada tanggal 10 Oktober 2017 di Makassar.
Yasir, M, dkk. 2013. Pengembangan Lembar Kerja Siswa (Lks) Berbasis Strategi Belajar Metakognitif Untuk Meningkatkan Hasil Belajar Siswa Pada Materi Pewarisan Sifat Manusia. Jurnal Bioedu, 2(1): 7783.

Yazar, Soyad1, B.B. 2015. Creative and Critical Thinking Skills in Problembased Learning Environments. J. Gift. Educ. Creat. 2, 71-71.

Yunianti, Hesty, dkk. 2016. Pengembangan LKPD Tema Pencemaran Lingkungan Berbasis Problem Based Learning Untuk Meningkatkan Keterampilan Berpikir Kreatif. Jurnal Pengembangan LKPD IPA, FMIPA Universitas Negeri Yogyakarta, diakses pada tanggal 15 Februari 2018 di Makassar. 